\title{
A CLINICAL AND HISTOLOGICAL STUDY OF LINGUAL CANCER
}

Part I. Clinical and statistical study on 65 cases of lingual cancer.

\author{
By \\ Toshiro GOTO M.D., KenJiro YANAGINO M.D., \\ $M_{A S A O}$ HIGUCHI and SANETOMI EGUCHI \\ From the Dept. of Oto-Rhino-Laryngology, Nagasaki University \\ School of Medicine. (Director: Prof. Toshiro Goto)
}

Clinical and histological study was carried out on 65 cases of lingual cancer, which underwent glossectomy with neck dissection during the period from 1952 to 1963 in the Dept. of Oto-Rhino-Laryngology, Nagasaki University Hospital.

The clinical and statistical aspect of this study is reported here as the first part.

1. According to the statistics of mortality in Japan in the period from 1950 to 1958 published by the Bureau of Statistica Ministry of Welfare, the incidence of lingual cancer in Japan is $0.5 \%$ of all cancer.

However the statistical investigation of the tumor incidence in all tumors in Nagasaki City fsom 1957 to 1959 , revealed the incidence of $1 \sim$ $1.5 \%$.

2. The majority of the cases was in the age group of 40 to 60 years.

3. Male showed $73.9 \%$ while female was 26.1 $\%$.

4. Among the etiological factors of tongue cancer, the poor dental condition was found in the highest incidence of $86.1 \%$.
5. The tumors were located in the body of the tongue in $91 \%$, particulary in its edge. whereas only 4 cases were found in the root of the tongue.

6. The clinical appearance of tongue cancer are. so varied that the authors have classified it into the following six forms.
1) Leukoplakia form
2) Erosion form
3) Ulcer form
4) Tumor form
5) Mixed form
6) Submucous deep form

7. The histological examination revealed squamous cell carcinoma in most cases, (64 out of 65 cases).

8. The clinical stage of lingual cancers weredivided from I to IV by the authors, and while$44 \%$ on the I st stage and the $40 \%$ III rd stage was found very few cases were seen in II and IV stages.

The histopathological findings will be reported in the forecoming publication of the II nd part of this study. 


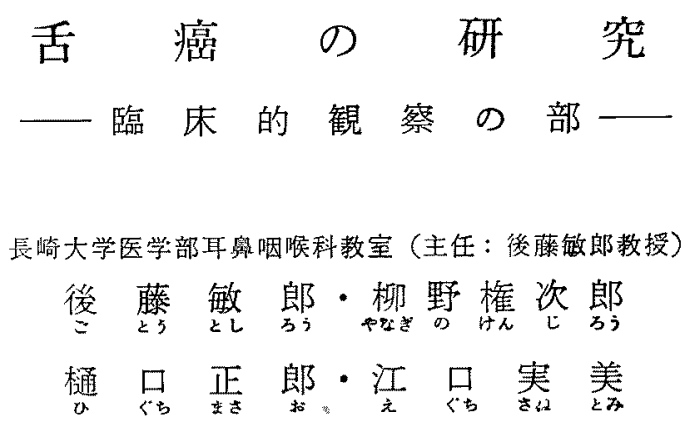

癌関する研究が盛儿であることに較らべると，舌癌 比関する, 報告は極めて少ない，その理由は，舌癌の発 生頻度が低いことによると思われるが，むしろ，その取 披われている分科が耳鼻咽喉科のみでなく， 口腔外科， 外科，放射線科，等に亘つているからであるう.

われわれは，一定の術式のもと住手術を行つてきた舌 澏症例が 1952 年 1 月上り 1963 年 6 月までの間に 65 例 に達したので，この65例について綜合的な観察を試み た. 観察の対象とした例は，いずれも舌を原発部位とす る. 所謂 primär の舌癌を選んた゚。既に 50 例の統計は 1961 年に報告したが，今回怡綜合的な 観察結果を「臨 林的観察の部」、病理組織学的観察の部」「治療とその 予後の部」K分つて，報告することとした，先ず，ここ 儿「舌癌の臨床的観察の部」を報告する。

\section{舌癌の歴史}

舌癌の古い時代の文献については，凟料を得るに困 難な立場にあるので， Martin の History of lingual cancer ${ }^{1)}$, Pack and Ariel $\odot$ Tumor of the head and neck ${ }^{2)}$ 及び Berridge and James $の$ The management .of lingual cancer 6) に記載されたものを抄録すること とした.

舌癌についてふれた最も古い文献は，Ebers papyrus (about 1000 B.C.) に括る記載 (Illness of the tongue) であつて，その後は Hyppocrates (460〜370 B.C.), Albucasis (1013 1107 A.C.), Guy de Chauliac (1300〜1368 A.C.) 等の報告があるが，その記載は極め て少ない.

17 世紀敒入ると, 1635 年, Alexander Read が舌癌 について比較的確実な報告をなし，1658 年には Pimpernelle が初めて舌の手術を行つており，1664年，Marchetti が舌の悪性腫瘍の切除を行つている.18 世紀に 入ると, 1743 年, Heister に上つて舌癌の手術につい ての記録が残されて拈り，19世紀に入つてよりは多く
の報告が見られるようになつた． 即ら，1803年 Inglis は舌適瘍周囲を口内から針を用いて縫合することを始め て㧍り，1819年, Langenbeck は wedge-shaped excisionを紹介した。

その後, Mirault, Jaeger, Maisonneuve, Collis 5 は舌動脈の結禁之賽部切開に上る舌の切除術を行い, 19 世紀の後半沈は Roux, Sedillot, Syme, Billroth, Langenbeck らは下顎切除によつて舌切除を行つた。 Regnoli, Czerny, Billroth, Kocher らは既に経顎下的 手術を紹介している，20世紀になると放射線療法も行 なふれれるようになり，1922年，DicksonはX 線を用 い, Dominichi は Radium を用いて舌癌の治寮が行わ れた. 1914 年に Steavenson は Radium の Implant* ation を行つている。一方, Crile は既に1906 年にRa. dical Neck Dissection を行つているが， その成續は樫 めて不良であつたから，一般の注意を惹く至らなかか た. 戦後，化学療法，麻唒，之の他，関連分野の進歩上 相侯って手術子その手術範围を一段之桩大し，口底及ひ 頸部の廓清と相侯つて，その成續を挙げるようになった がその間の文献については関係の各項に执いて挙げるこ ととする。

\section{舌癌の発生頻度}

わが国に括ける舌癌の発生頻度を調査したものとして は，長与博士の病理解剖統計があつて，現在まで展々引

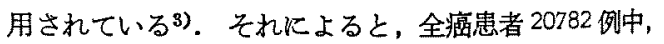
舌源患者は 421 例で， $2.03 \%$ となつている. 又, 東大山 極㴚理，及び名古屋好生館の癌死亡統計拈いても，舌 癌例は $2 \%$ 内外を示している，その後には，大きな統計 を発見することはできなかつたので，最近の状態を知る ために，われわれは次のような調查を行つた。

厚生省の悪性新生物死亡統計 4) より昭和 25 33 年の

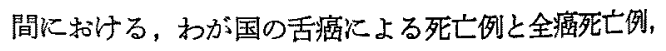
全死亡数とを引用して，その割合を表示すると表 (1) 
表 1

\begin{tabular}{|c|c|c|c|c|c|}
\hline 年度 & $\begin{array}{l}\text { 舌癌 } \\
\text { 死亡数 }\end{array}$ & 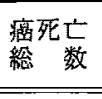 & 総死亡数 & $\begin{array}{l}\text { 癌死亡数 } \\
\text { に対 } 5 \\
\text { 舌癌 } \% \\
\end{array}$ & $\begin{array}{l}\text { 临死亡数 } \\
k \text { 刘する } \\
\text { 舌癌\% }\end{array}$ \\
\hline 25 & 321 & 64428 & 904876 & 0.50 & 0.04 \\
\hline 26 & 291 & 66354 & 838998 & 0.44 & 0.03 \\
\hline 27 & 311 & 69488 & 765068 & 0.45 & 0.04 \\
\hline 28 & 335 & 71578 & 772547 & 0.47 & 0.04 \\
\hline 29 & 311 & 75309 & 721491 & 0.41 & 0.04 \\
\hline 30 & 384 & 77721 & 693523 & 0.37 & 0.04 \\
\hline 3I & 308 & 81879 & 724460 & 0.38 & 0.04 \\
\hline 32 & 345 & 83155 & 752445 & 0.41 & 0.05 \\
\hline 33 & 303 & 87895 & 684189 & 0.34 & 0.04 \\
\hline
\end{tabular}

のようである。

これによると，毎年における舌癌による総死亡数は約 300 例であつて，特に增加の傾向も減少の傾向も見られ ないが，全癌死亡例に対与る舌癌例の割合は， $0.5 \sim 0.4$ \%前後走して出り，しか曲，昭和 25 年よりわずかな がらその死亡事は次第に減少の㑯向宗している。この ことはいかなる意味を持つかは不明であるが，治癒率の

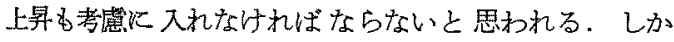
し，以上のような死亡あるいは剖検の統計では真の発症 率は不明である。

幸に現在，長崎市においては，市医師会及び米国原爆

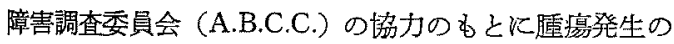
精密な調查が行なるれているから，この調查を利用して 舌癌の発生頻度を調查することとした。この長崎市にお ける腫瘍発生調查の5ち，1957〜1959年の3カ年間の

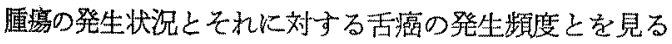
と表（2）のようである。

この統計仙局地的で，乙か子，原爆被爆地とい5特殊 な地域のすのではあるが，調查が正確なことと，死亡統 計や病理解剖例に上る統計とは異り，壆の発生総数を示

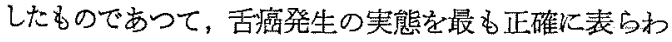
している点に和いて，貴重な資料である，即ち，この統 計から明らかなことは，全癌に対劣る舌癌発生の割合 は, 約に〜 $1.5 \%$ を示して物り，この値は愿生省による

\section{丧 2}

\begin{tabular}{|c|c|c|c|}
\hline 年度 & $\begin{array}{l}\text { 舌 癌 } \\
\text { 登生数 } \\
\end{array}$ & $\begin{array}{l}\text { 全 癌 } \\
\text { 発生数 }\end{array}$ & $\begin{array}{l}\text { 全癌数に対 } \\
\text { する舌源\% }\end{array}$ \\
\hline 32 & 14 & 911 & 1.5 \\
\hline 33 & 9 & 975 & 0.9 \\
\hline 34 & 10 & 943 & 1.1 \\
\hline
\end{tabular}

死亡統計が示した． $0.4 \%$ 0.5\%に比較すると，約2〜3 倍の高い值を示しているが，長与の剖検統計及び従来の 外国の発生率の統計には近い値を示している。全癌に刘 する舌癌の真の発生率を示した報告は，放が国では発見 できなからた。

長畸大学附属病院で取扱つた全癌に対する舌癌の割合 を調查することも图難であつたが，この問題については

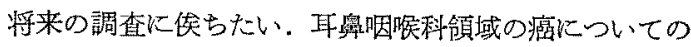
統計によると，1952年〜1961年の10年間に取报つた舌 癌症例は 59 例であり，同じ年間に取扏つた耳舆咽㩔科 領域の浣症例は291 例であつて，その約 20\%を是めて いることになる. 大谷 ${ }^{5}$ によると昭和 27 年〜31 年の間。 に東京医科歯和大学口腔外科教室で取扱つた121 例の口 腔癌の5ち 18 例が舌癌であつて, 14.9\% となつている. このこもから，耳鼻咽知利領域での舌癌の重要性が示さ れていると思ら。

以上の統計がら，わが国に和仔る舌癌発生の実態とそ の推移を知ることができる。

海外に和ける舌癌の発生頻崖については, 全体的な続, 計のものでは, Berridge ane James ${ }^{6}$ )によると全癌の $2 \sim 3 \%$ ，剖检例の1〜2\%であるらとされている。その 後の交献は殆んぞこの做を踏翼している，報告者の所属 病院の統計は少くないが, そのらちの2.3のものを挙げ ると, Rahausen and Sayago (Santigo) ク)の統計では, 1930年〜1944 年の間に和ける全癌 10,000 例中に 113 例, 約 $1 \%$ の舌癌を報告している. Ariel, Cross and Gibbel 8) Illinoi $\odot$ Veterran Administration Hospital に甜する1931年〜1946年の間の統計では，全癌 17327 例中，口腔癌が 1299 例 (6.3\%) で如つて，舌癌は 368 例 $(1.8 \%)$ となつている。 Martin ${ }^{9)}$ の報告から New York City の死亡絸計を見ると，舌癌は同市全癌の1.2 \%とされるが，人類の全癌に対しては2〜3\%と推定さ れると云つている. J. English 10)によるとインドでは 1000 例の口腔癌の中で 522 例が舌癌であると報告して いる. Palmer ${ }^{11)}$ らによると Montreal General Hospital で1955年〜1959年の間に取扱つた舌癌は100例 であつて，これは同期の雭性堙渲総数の $1.58 \%$ 亿相当 するとしており，1952年から1956年の間に括斿る同地 万の死因では，舌洗死は $0.69 \%$ であると報告している。

以上の外国の文献と最近わ孙れが調查したわが国に

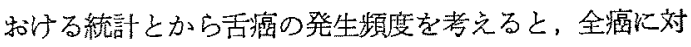
する舌癌の発生頻度は外国の 2 3\%の発生頻度に比較 してやや低く，1〜2\%の発生頻度であること，死亡統 
計に上るものでは更に低く，0,5〜1\%であることが明ら かとなつた。

\section{舌癌の好発年令と性別}

舌澏の好発年令についての統計からは，文献に批いて む特に注目すべき所見は億められていない，即ち Raha・ usen and Sayago 7) 50 才代, Dargent 12) 21) 22) は60 才代化多人，Palmer ${ }^{11)}$ 5は60 80才 Marchetta ${ }^{13)}$ らは50〜70才，English 10) は45〜60才似多いとして いる. 古いものでは Ehrlich 3) 14) 任60 70 才, Bultin 15) は 45〜60才とし，各郝告者の間に殆儿と大差が㒛め

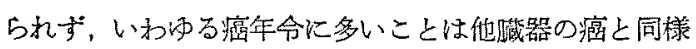
である。

舌癌患者の平均年令化つてては，Ash ${ }^{34)}$ は 63 才 Gibbel ${ }^{8)}$ らは52.6 才; Martin ${ }^{9)}$ は58 才であると報告 している. 我国に和ける統計では，各報告の示す值に大 差なく 40〜60 才に多い.

われわれの統計でる表（3）に示すごとく，40４9才

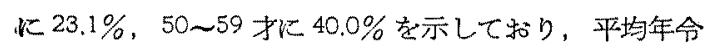
は50.9 才となつている。しかし，㜔は制合に若年者 炕も多く, Frank, Wallace, Enfield. Miller 3) とよれ ば，初生児の例が報告されている．その他の 2.3 のの を表（4）に示すと10才台に3例の報告が認められてい

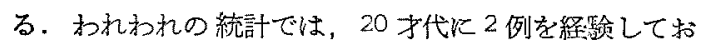
ウ，最年少者は26 少の男子であつた。

\begin{tabular}{|c|c|c|c|c|}
\hline$=\frac{\mathrm{s}}{\mathrm{p}}$ & 3 & 우 & 計 & $\%$ \\
\hline$\sim 27$ & 1 & 1 & 2 & 3.1 \\
\hline $30 \sim 39$ & 8 & 1 & 9 & 13.8 \\
\hline $40 \sim 49$ & 10 & 5 & 15 & 23.1 \\
\hline $50 \sim 59$ & 20 & 6 & 26 & 40.0 \\
\hline $60 \sim 69$ & 7 & 2 & 9 & 13.8 \\
\hline $70 \sim$ & 2 & 2 & 4 & 6.2 \\
\hline \multirow[t]{2}{*}{ 部 } & 48 & 17 & 61 & \\
\hline & & 表 & 4 & \\
\hline \multicolumn{2}{|c|}{ Martin } & 17 & 小 & 1 侧 \\
\hline \multicolumn{2}{|c|}{ Rahausen } & 10 & 才代 & 1 例 \\
\hline \multicolumn{2}{|c|}{ Gibbel } & $3 !$ & $-x$ & I 例 \\
\hline 桐 & 谷 & 16 & $-(8)$ & 1 例 \\
\hline \multicolumn{2}{|c|}{ 椯 } & 30 & 才 & 8 例 \\
\hline 4 & 下 & 20 & 才代 & 4 例 \\
\hline
\end{tabular}

舌癌が男性に多いことはいづれの文献にも示されて いる. 男女間の生活様式, 刺激性嘴好物の差異, ある いは素因等によるものであるう．男女の比率について は, Cade and Stanley ${ }^{16)}$ は79\%に男性が多いとし， Martin 9)は87\%, Rahausen は $86.8 \%$, Marchetta and Mattick ${ }^{13)}\left(79 \%\right.$, Sprindrich ${ }^{17)} は 81.8 \%$ ，標 18) $282.1 \%$ ，石川 ${ }^{19)}$ 《 $77.3 \%$ ，金田 ${ }^{20)}$ は $66 \%$ ，長 与は $81.2 \%$ ，桐谷 ${ }^{3)}$ は $61 \%$ ，といずれも男性江多発す ることを報告している。

われわれの統計では男性 $73.9 \%$ ，女性 $26.1 \%$ であり， 男性之女性の比は約 2.8:1 で文献炕示された比彎炕近 w.

\section{舌癌の誘因（表 5)}

舌癌の誘因として古くから内外の文献に挙げられてい

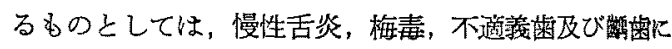

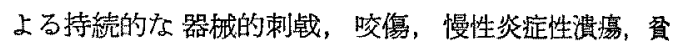
血，タバコ，领酒，白珽症等が挙げられているが，この． うちで，海外の文献では，舌癌患者に血清梅毒反応の晹 性率が高いことから，梅毒に上る舌の慢性炎柾刺钱と梅

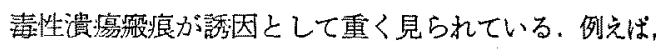
梅毒陽性率については, Rahausen 7) 30\%, Martin 9) 28) 33\%, Schrener and Brown 24) 4\%, Jacabson 95$) 14 \%$, Prieto ${ }^{26)} 80 \%$, Gibbel 8$)$ 5 21.8\%, Scarp and Spickermann 27$) 13 \%$, Wookey ${ }^{28)} 8 \%$. Berridge and James 6) $12 \%$ な゙が最近の外国に就りる報告の主なるもので 古る、方が国の統計では，榙（1925 年) ${ }^{18)}$ は9 95 例中 15 例 $15.88 \%$ ，金田 ${ }^{20}$ (1933 年) は34\%，梅谷 (1942 年)

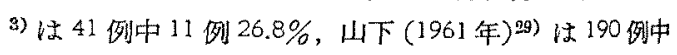
に約 40\%に陽性が得られている。

\begin{tabular}{|c|c|c|c|c|c|c|c|c|}
\hline 锈因 & 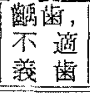 & 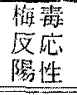 & 外管 & 燃䔶 & 酒 & 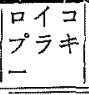 & 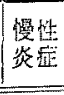 & 遝云 \\
\hline 例数 & 56 & 13 & 2 & 42 & 33 & 3 & 3 & 3 \\
\hline
\end{tabular}

われふれの䊺計では 65 例中 13 例，20\% の陽性率が

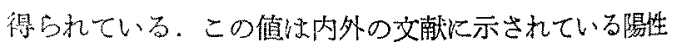
率のほ注中间炕近い值であるが，顕症梅毒症状を認めら れな症例恃発見できなかつた，血清反応が陽性であるこ とが癌の発生に対して持つている意義についての説明蛙 困難でするが，外国の統計における各報告者の值の差の 大きいことから見ても，重大なる意義を持つているすの とは考完られない。 
中 24 例，58\%われわれの統計では，65 例中 29 例, 約 45\%に疼痛を訴えた。

その他, 初発症状として訴光る症候は, ヒリヒリする 感じ，チクチクする感じ等の異常感が多いが，自ら硬結 を感じたり，潰瘍が認められるようになつて始めて医家 の門を訪らのであるから, 舌癌に拈いても初期癌, 即ち Carcinoma in Situ あるいはこれに近い状態で診断を 受ける例は極めて少く，われわれの統計では僅かに1例 に過ぎない。

\section{舌癌の臨床上の病型}

舌癌では進行した状態になつて始めて診断が決定され ることの多いのは, その病像に一定したものがなく，腫 瘍として一般の頭の中に築かれている病像とは異つた型 のものが少くないからであろら.

舌癌の病像を山下 ${ }^{29)}$ は外向性 (非浸潤型)，内向型 (浸潤型)，表在性の三型に分つている。桐谷 ${ }^{3)}$ は表在 性と深在性とに分ち, 表在性のものは扁平上皮癌, 深在 性のものは主として粘膜の腺より発生する円柱細胞癌で あるとした。

海外の文献では， Morrow ${ }^{35) ~ は ~ p a p i l l o m a t o u s, ~ t u-~}$ mor, ulcerative の3型に分ら, Cade 16) らは潰瘍型，

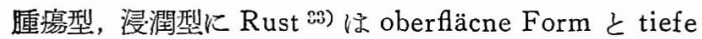
Form に分類している.

われわれの 65 例の統計からみると，舌癌の病像はむ つと多様性であつて, 少くとも, 次の6 型に分類するこ とができた（表6）.

\section{表 6}

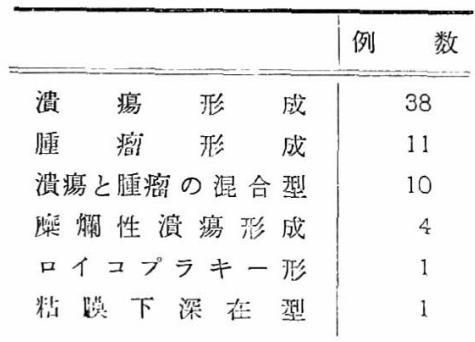

1）ロイコプラキー型（図 1)

舌粘膜の一部に小白斑を呈し，Lenkoplakia の外見 を示している例で, 従来 Leukoplakia として一つの病 変として取扱われたが，組織標本では既に Carcinoma in Situ の所見が認められるもの，あるいは，舌癌の初 期癌と考劣られる例があるから，舌癌にも斯る病変の存 在を認めなければならない，多くの舌癌がすべて斯る病

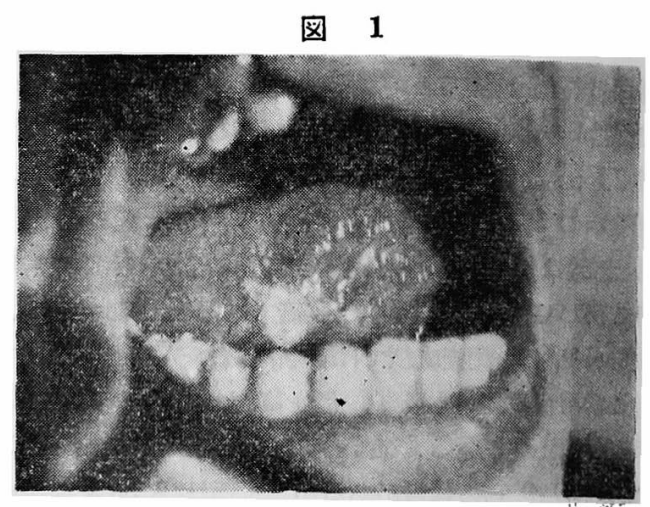

图 2

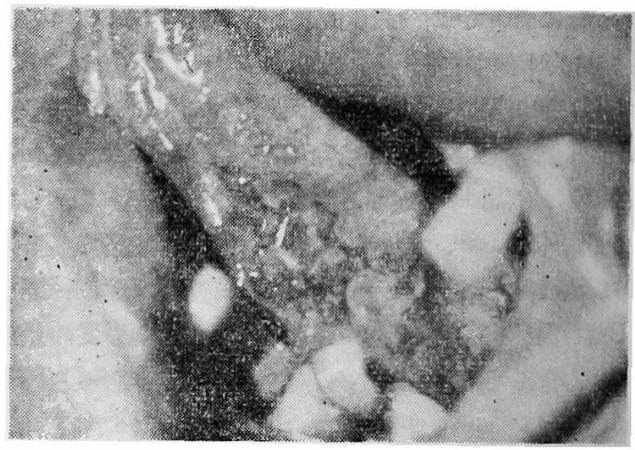

変を経過与るもので㐫るかどらかは不明である。この型 のもののう台には，既にその一部に小潰㾮を形成してい るものは合まないこととした．

2) 糜爛性潰湯形成型（図 2)

この型の舌癌は，糜爛状の極めて浅い，不規則な潰㾤 を形成し, この潰瘍が匍匐状に拡大して, 深部に向つて 浸潤しない型のものを指すのであつて, 一見, 慢性炎症 性の潰瘦を思わせる極めて特異な病型のものである.わ れわれは斯る 1 例を 2 年の長期に亘つて観察したが, 深 部へ浸潤の傾向なく経過したが, 治癒の傾向を認めなか つたために，ついに舌切除を行つた. 斯る型の舌癌は文 献にも発見できない新らしい型のものである。

3）貲激形成型（図 3)

これは舌癌の最も多い型であつて, 周緑の漫潤隆起を 欠き, 深い潰瘍を形成するものから, 周縁の隆起した潰 瘍まで各種類が認められるが, 周縁隆起の軽い例では慢 性の特殊炎症を思はせる。

4) 畦瘤形成型 (図 4)

舌の表面に隆起して腫瘤を形成する型のもので，結節 状の隆起を形成したもの, 表面乳嘴状を呈するもの, 扁 
平な隆起を形成しコンヂロームを思われるもの等, その 種類訬くない，一見して，パピロームヌは良性の腫瘍 を思わしめる型のるのである.
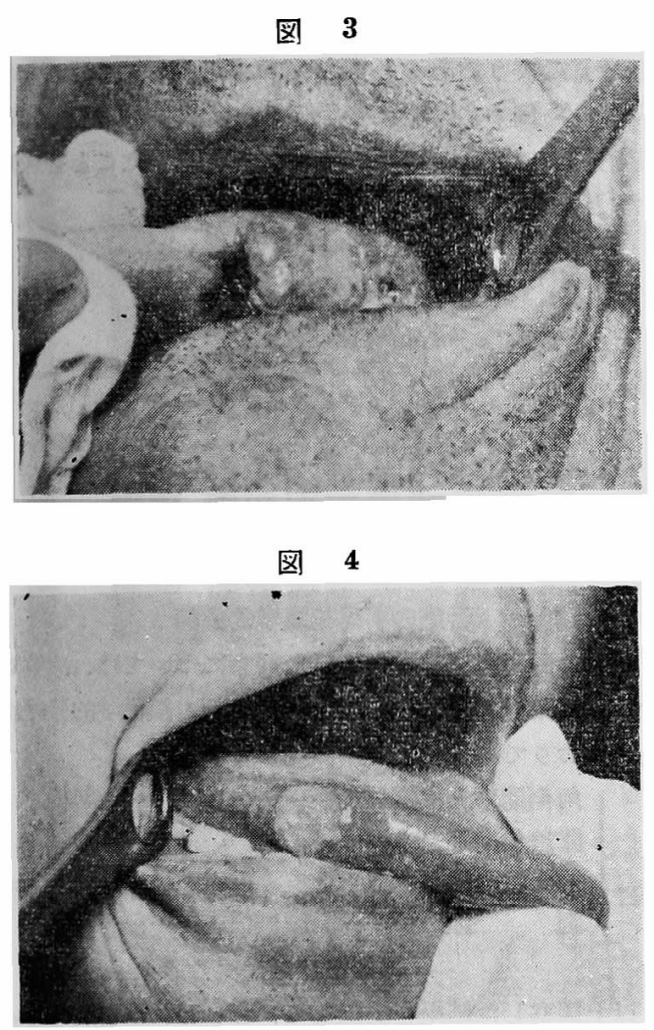

図 5

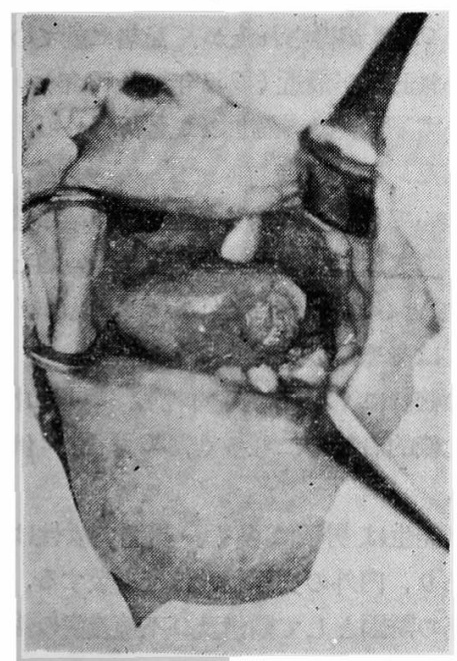

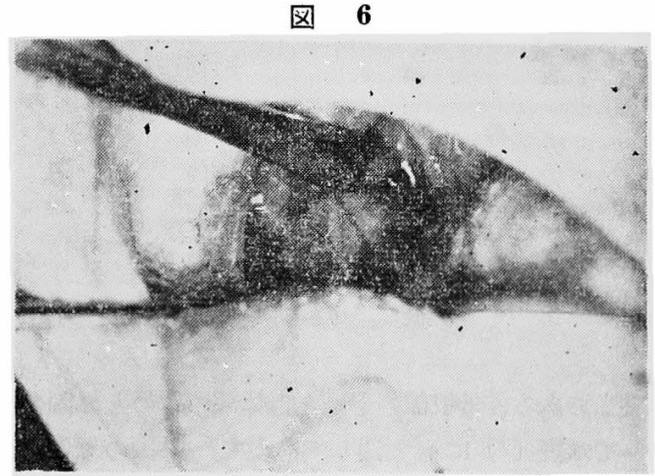

5）潰瘍と腫瘤の混合型（図 5)

腫瘤状に潰痗縁の隆起が強い例で，最も癌蕾らしさを 思わせる型のものである.

6) 深在型 (粘膜下) (罒6)

舌根部に発生し, 粘液腺より発生したと思われるるの である，比較的進行するまでは粘膜下に在つて，潰瘍化 が遅く，一見して良性の畽唔を思わしめる。

\section{舌癌の発生部位}

舌癌の発生部位は舌の組織の 発生原基の上から見て も, 図 (7) の如〈舌体部 (前 $2 / 3$, 即ち Papilla Vallata の前) 及び舌根部 (後 $1 / 3$ ) に分つて観察されるの

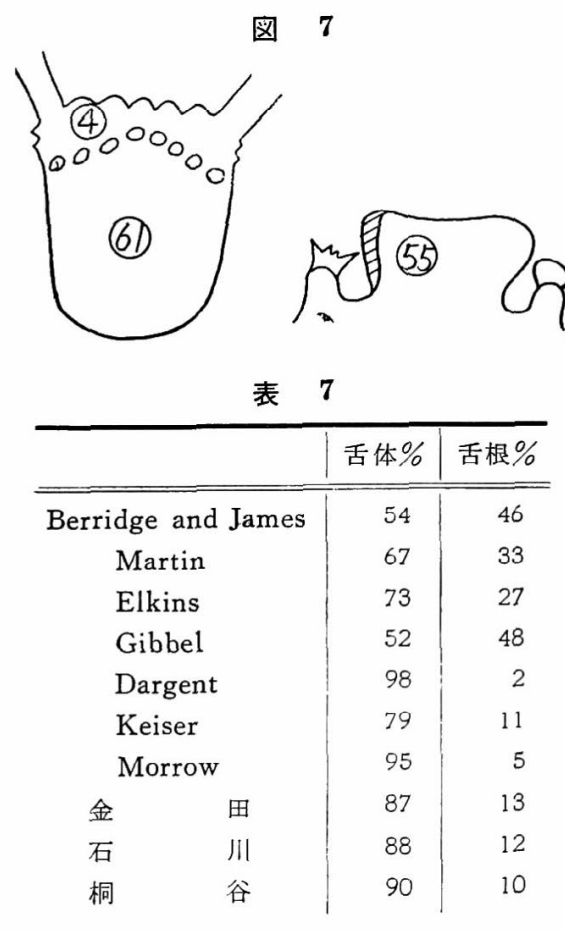


Tabcco 及び Alkohol が常に誘因的刺㦸となり舌炎 を萑起すると考光られて調查されて来ているが，いずれ の文献からる特仁有意義と見られる成績を得ることは困 難である.Martin 9) によれば米国では煙草の常用者は 男子では75\%，女子では9\%というから，垔草の誘因 的な意義は決定し難いが，それでも，常用者は非常用 者に対して，舌澏䍜患率は2 倍であると告している. Gibbel ${ }^{8)}$ らの調查成䋶では舌癌症例のうちで等草を高 度火常用する例が $58.1 \%$ ，酒を高度に常用する bのが 45.7\% となつている. 古いるのでは Bergmann 3) 30) Ehrlich 3) 14) らの報告があるが，いずれも30\% 前後の 值を示している。

かが国に括いては，金田 20)《44 例中23 例, $52.5 \%$,

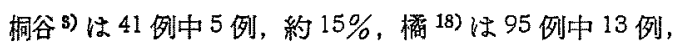
約 $14 \%$ ，石川 ${ }^{19)}$ は 17 例中 6 例， $52.4 \%$ となつている. Alkohol K関して子同梯化金田 ${ }^{20}$ ) $45.4 \%$ ，梅谷 ${ }^{3)}$ は約 $15 \%$ ，石川 ${ }^{199}$ は $52.4 \%$ ，桶 ${ }^{18)}$ は $11.4 \%$ を示して いるが，外国に怙いても殆んどの報告が有意義であると いら成續は得られない，われわれの調查では煙草，酒を たしなむ例が約 65\%であつたが，これは中等度の量の ものをむ含んだ值であるから，重要な恙議があると思え ない.

舌癌の誘因のうちで，最も意義があるものは䧽雪又は 不適義菊に上る持続性の器械的刺战の問題であり, これ はVirchow の Reiztheorie からも理解することか゚で

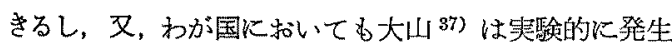
させることに成功している，この問題については，桐谷 3) は 44 例中 10 例 (約 22\%)，㰌 18） は95 例中 5 例（約

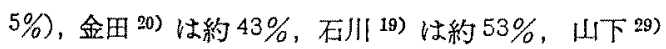
位 190 例中 76 例 (約 40\%), 外国では Bergmann 30) 21,6\%, Ehrlich 14) 10\%: Martin 9) 約 10\%, Schreiner 24) らは 10\%, Rahausen 7 約 $15 \%$, Gibbel ${ }^{8)}$ 約 $37 \%$ といら報告がなされていてその值の养異の幅が大きい

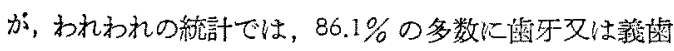
の持統性刺戝に上ると思われる例が認められている. 山

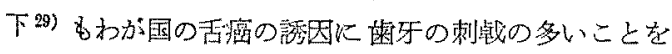
特水挙げ，190 例中76例，約 40\% を報告している. 我 国の過去の統計では上記のごとく，㴽因としての率の低 い報告もあるが，これは注意のいかんと判定の方法とに よるものと思ら．われわれの統計は特に高い率を示して いるが，わが国の報告には外国のるのに比して高率のも のが多いことは注意すべき問題と思う。周瘍が発生した ために柴牙との接触が起つていると見る見方もあるが，
宷牙の断端つ鋭利なることなどよりみて，誘因と推定す るのが妥当だと思われる例が函るて多い，明らかに管傷 後に発生した例は 1 例報告されている例を見る，われわ れの統計に括いては咬傷後上り発生した例を1例経寎し ている.

ロイコプラキーを誘因とすることについては，このす のを誘因と見做すこと自体阔閴がある。しかし、こ れに関する報告をとの立げてみると， Rahausen?

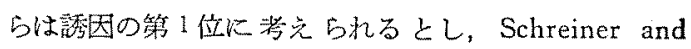
Brown 24〉有意義なることを報告している。発現率儿 つては, Bergmann ${ }^{30)} 34 \%$, Steiner ${ }^{32)} 23 \%$, Gibbel 8) (4 10\%, Palmer ${ }^{11)} 11 \%$, Martin 9) (456 例中 1 例 に見られたとしている，わが国に执いては，樀 ${ }^{18)}$ $9.5 \%$ ，金田 ${ }^{201}$ は約 7\%，桐谷 ${ }^{3)}$ は約 10\% 等が政献に 挙げられている。

Leukoplakiaは，古くは舌癌の誘因として取扱われ ているが，舌癌の前段陵である場合，あるい恬既に舌癌 である場合があるために誘因と見做すことは妥当でな い. 古〈は Bergmann ${ }^{30)}$, Steiner ${ }^{32)}$ らの報告に見ら れるごとき高率の成績が報告さ礼ているが，最近は本症 を誘因として取报つている報告は少くなつている，斯る 問題の決定は極めて初期よりの経過を微察することによ つてはじめて可能であつて, われわれの調査では, 組織 学的に Leukoplakia の診断で 1 年後に癌性の变化をき たした例を1例経影したが，遡つて標本を再検してみる と，この例に招いても既に当時 Carcinoma in Situ と 見做される所見が発見できた。同様所見を Lucas ${ }^{3)}$ は 1554 例の舌痌中に 1 例報告している.

慢性炎症は癌発症の重要な条件と考元られる説がある が，和れわれの統計では，特殊な炎症を誘因とした例は

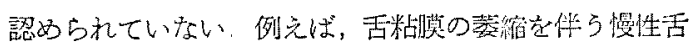

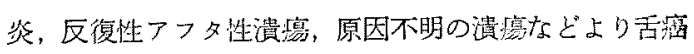
の発生した例没認奶られていない

\section{舌癌の初発症状}

舌癌の初期飞は症状を欠人例が多小，初発症状の5ち で間題になるのは疼痛である。疼痛も舌癌の病型に上 つて舆り，ての発現は必す゚しも一定しない，增殖性の 例では疼痛のない例が多々，溃瘄形成例では疼痛が強 い，初発症状としての疼痛を数值的に示したものは， Gibbel ${ }^{8)}$ らの統計であつて 40.6\%。 その5ら疼痛か比 較的強いものが $23.6 \%$ としている. Schreiner ${ }^{24)}$ らは 症状のない例が半数であるとしている。 Martin9は疼 痛を自覚したものが多いとし，桐谷 ${ }^{3)}$ の報告では41 例 
表 8

\begin{tabular}{|c|c|c|}
\hline 舌 & 体 & 61 例 $(91 \%)$ \\
\hline 臬 & 縁 & 55例 \\
\hline 舌 & 背 & 2 例 \\
\hline 舌 & 资 & 3例 \\
\hline 舌 & 下 & 1例 \\
\hline 向 & 根 & 4 例 $(9 \%)$ \\
\hline
\end{tabular}

が妥当である、舌根部のものと舌体部のものとの割合に ついては表（7）に示す通りであって，外国の報告と比 䡆するとわが国の報告では舌根部のものが極めて少な い、しかし，Morrow，Keiser, Dargent 等の如く低率 の報告もあるし，John Fraser ${ }^{39)}$ の報告では 47 例中舌 根のむのは僅か汇 1 例となつているから，外国江舌根癌 が多いとは思われない，われわれの調查では表 (8) に 示すごとく，舌体部のものが約 $91 \%$ でそのうらの約 85 \%は舌縁のむので放り，舌根部に発生したるのは，僅か 飞4例（約 $9 \%$ ）飞過ぎなからた。

以上の報告に認められるように，舌癌が舌体部に多い 点は各報告の一致しているところであるが，舌根部に特 に少いことについては次編，病理組織篇に拁いて述べる こととする。

\section{舌癌の病症 Stage について}

癌の進行状態の理解を容易にするために，その病症の Stage の分類基準は各種の癌について決定される傾向に ある。舌癌については未だその Stage の設定について の意見は発表されていない，舌癌の性質上その病型が単 一でないから，潰㾂や，睡瘤の大いさで表わすことは適

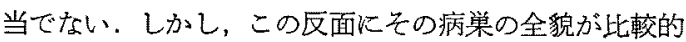
容易に判定できる状態にあるために Stage の分類は基 準の設け万のいかんによつては比較的容易と思方九る。

次の Cristie Hospital 及び Holt Radium Institute が用いている，一般の癌に用いた基準が 舌癌の Stage の分類にも適当かと思的るので，これを舌癌に用いて 次のようにその基準を設定した

第 1 期：病集が初発部位（舌体又は舌根）飞限局し，

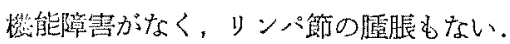

第 2 期：病栄が初発部位（舌体，舌根）より隣接の 組織に波及したもの（口底粘膜，歯肉，下顎骨，舌口蓋

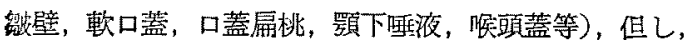
ンンパ節の腫脹はないるの.

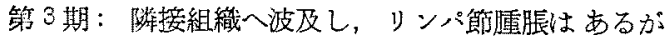

（上頸部に限局し），しかも未だ可動性のもの.

第 4 期：隣接組織への 波及上共に(頸部) リン八節 の転移が非可動性であるすの（可動性であつても项部全 般に及ぶもの).

以上の基潐によつて，われわれの65例を分類すると 表（9）のようである．即ち，第 I 期及び第而期のるの が夫々 65 例中 29 例及び 27 例で，断然多いことは，早 期発見例と共にリンパ節転移の比較的速かなととを意味 すると見做すべきか。

\begin{tabular}{c|r}
\multicolumn{2}{c}{ 表 } \\
\hline Stage & 症 例 数 \\
\hline I & 29 \\
II & 4 \\
III & 27 \\
IV & 5
\end{tabular}

舌癌の病理組樴学的分類

舌癌の病理組織学的な詳細な推察については，次箁に おいて報告する予定であるが，65 例の組織学的分類恃 次のと拉りであつた。

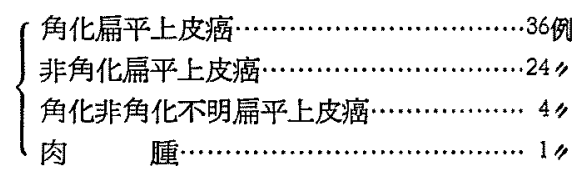

総括及び考按

以上観察した結果を総括して，われわれは舌癌につい ての知見を次の如く整理した.

1) 和が国の舌癌の発生頻度は最近の全国死亡統諳加 らは全癌の $0.5 \%$ が得られたが，患者に就ての真の発生

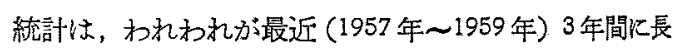
崎市において調查した統計では 全癌の 1 ～1.5\% の発生 率が得られた。

外国に批いても患者に就ての舌癌の正確な発生統計を 知ることはできなかたが，一般的な推定値として，全 癌の 2〜3\%とされているが，これより見れば，かが国 の発生頻恬はやや低いと見るべきか。

2) この統計に特ける好発年令は 40〜60才であり， 乙か子，比較的若年者にも多く，20才代，2例，最年少 者は 26 才。

3）性別発生は男子江多く，男性対女性は $73.9 \%$, $26.1 \%$ であり，内外の文献值とほぼ一致する。

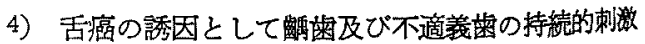


によると思われる例が最も多く，われわれの調查では 86.1\%であつた.

海外の報告に比して，わが国の報告には慗の刺激を誘 因とする率が高いが，われわれの值は最も高いものであ る.

5）発生部位は舌体に多く，われわれの例では $91 \%$ であり，特炕の舌縁部に多い。

海外炕は舌根に多い報告もあるが，この值は多くの報 告と一票している。

6) 辞澏の外見は多様であることから，われれはロイ

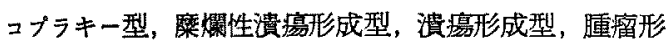

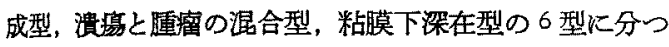
た.

7）病理組織学的には扁平上皮癌がその殆んどを占め t.

8）舌癌の病症の Stage の基準を提案し，これによ って I〜N Stage K分った. I 及び吕 Stage が夫々， 44\%〜 40\%を示めしI及びN Stage は極めて少数であ つt.

9）初期には热症状な例が多い，疼痛を訴える例は半 数であり，異常感を訴える例も多い。

次篇は「告癌の病理組織学的研究」

$$
\text { 文献 }
$$

1) E.H. Martin: History of lingual cancer. Amer. J. Surg. 48 : 703 716, 1940.

2) G.T. Pack and I.M. Ariel et al: Treatment of Cancer and Allied Diseases (Vol. 3. Tumor of the Head and Neck).

3) 桐谷信蜼：かが教室最近10年間に和ける舌癌患者の

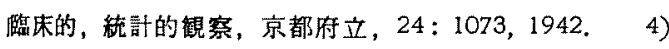
㴟生省公臬衛生局：昭和 33 年第一次悪性新生物実態調 查，厚生省大臣官房䋽計調査部：昭昭 34 年人口動態統 計下巻. 5) 大谷隆次：最近 5 年間に当教室を訪れ

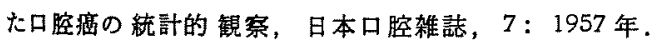

6) F.E. Berridge, A.G. James: The management of lingual cancer. Surg. Gynae. Obst. 103 : 595 606, 1956. 7) A. Rahausen, C. Sayago: Treatment of carcinoma of the tongue. Amer. J. Roentgenol. $71: 243 \sim 250,1954$.

8) M.I. Gibbel, J.H. Cross and I.M. Ariel: Cancer of the tognue. A Review of 330 cases. Cancer. 2: 411 423, 1949. 9) H.E. Martin, H. Munster and E.D. Sugarbaker: Canerc of the tongue. Arch. of Snrg, 41 . 888 936. 1940. 10) J. English: Csncer of the tongue. A Review of the literature and a summary of two cases, with clinical histories and necropsy findings. Orsl Surg. and Path. 2: 231 247, 1949. 11) J.D. Palmer, M.M. Loughead, S.L. Martin: Cartinoma of the tongue. A Study of 100 crses at the Montral Leneral Hospital. Canad. J. Surg. 2: 180 184, 1959. 12) M. Dargent: Der Zer Zungenkrebs. Bull. Soc. intrenat. Chir. 16: 523 536, 1957. 13) F.C. Marchetta, W.L, Mattick: Carcinoma of the tongue. treatment and result without radical surgery. Surg. (St. Louis). 40: 378 386, 1956. 14) Ehrlich H.: Zur Statistik des Zungenkarzinoms. Arch. Klin. Chir. 88: 427, 1909. 15) Bultin H.T.: Illustration of veryuearly condition of cancer of the tpngue. Brit. med. J. 1: 1201, $1906 . \quad$ 16) S. Cade, E. Stanley: Cancer of the tongue. A Study based on 653 pstients. Brit. J. Surg. $44: 433 \sim 446,1957.17)$ P. Sprindrich, E. Brosch: Cancer of the tongue. Otolaryng. 6: 94 94, 1957.18$)$ 棌亮吉：舌癌以 関す万臨床的镜察, 福岡医学, 19:250, 1926. 石川善庭：舌癌の外科 臨床 観察，東京医誌，2770： 884, 1932 .20) 金田文平：舌癌の臨床的钼察, 日新 医学, $23: 1925,1933$. 21) M. Dargent, M. Mayer aud P. Bertoin: Der Zungenkrebs, eine zusammenfasrende Betrachtung mit therapeutischen Richtlinien. Ann. chir. 13: 135 155, $1959 . \quad$ 22) $M$.

Dargent, M. Mayer and P. Bertoin: Der Krebs der Zunge, Aetiologische, anatomische und kilnische sowie theoapeutische Gegebenheiten. Maroc med. 38: 805 833, 1959. 23) H.E. Martin: 5year endresults in the treatment of cancer of tongue, lip and cheek. Surg. Gyn. and Obsi. $65: 793 \sim 797,1938$. 24) Schreiner and Brown: Lnvestgation of the Results obtaind in cancer of the tongue treated by Radium and Roentgen. Amer. J. Roentgenol. 15: 207, 1926. 25) Jacobson: Carcinoma of the tongue. Acta Radiol. Supp. 68: $1948 . \quad 26)$ G. Prieto: Cancer de lengua. Acta Dermosifilioger. 41: 451 453, 1950. 27) Scharp and Spickermann: Cancer of the tomgue. Amer. J. Roentgenol. 57 : 181, 1947. 28) H. Wookey et al: Treatment of oral cancer by a Combination of radiotherapy and surgery. Annal Surg. 134 : 529 540, 1951. 29) 山下久蜼, 
他：舌癌の放射線治療，癌の臨床，7:4 号，1961。

30) Bergmann, E.: Uber Krankheiten, die dem Krebs vorangeben. Berl. Klin Wsch. 1905, 933.

31）飯沼寿雄：口腔癌誘発原としての㖪歯の意義，気 食, 2:2,1951。 32) Steiner A.. Die Zungenkarzinome der Heiderberger chirurgischer Klinik in den Jahren 1878 1888, Bruns Beitr. 6: 561, 1890.

33) S. Rust: Zum Problem des Zungen carcinoma. Ein Kassitischer Beitrag. Berl. med. 2: 270 274, 1951. 34) Ash, C.L.: Radiology of cancer of the tongue snd floor of the mouth. Amer. J. Roentogenol. 73: 611 619, 1955. 35) A.S. Morrow, M.D.: A Report of one hundred and eighty-seven cases, with an analysis of ninetyeifth treated principally by surgery at the new york skin and cancer hospital between 1917 1935, Cancer of the tongue. Annals of Surg. 105: 468, 1937. 36) 長与又郎：瘦の統計, 癌, 25, 1931. " , 26, 1932. ", 27, 1933. 37) 大山 栄蜼: 舌癌発生儿関する実験的研究，京付医誌，15: 127，1935，38）大谷隆俊：口腔癌の隔床病理学的研 究, 2報, 口腔会誌, $21: 192,1954$. 39) J.Fraser,; Carcinoma of the Mouth and Tongue, Annals, of Surg. 96:488, 1932.

（原稿到着 $=$ 昭和 38.8 . 30 日）

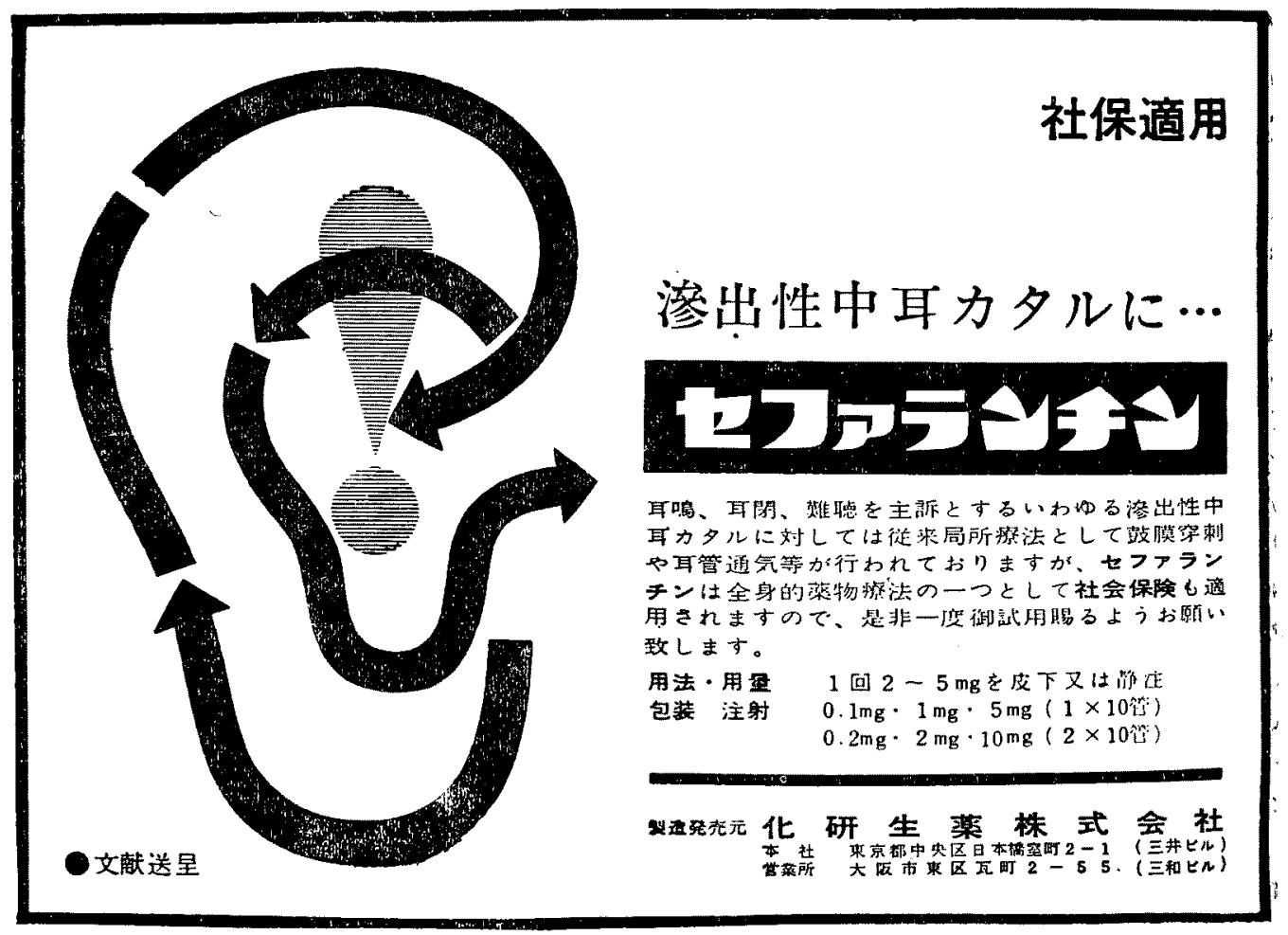

